\title{
“Knowing Your Body Well” Menggunakan Media Monopoli Sebagai Upaya Perlindungan Diri
}

\author{
${ }^{1}$ Boby Agil Prasetyo, ${ }^{2}$ Izza Lu'lu'ul Jannah, ${ }^{3}$ Tyas Ayu Putri Kiswanto, ${ }^{4 *}$ Yuniawatika \\ Universitas Negeri Malang; Jalan Semarang 5 Malang \\ *Corresponding author: yuniawatika.fip@um.ac.id
}

\begin{abstract}
Abstrak
Tujuan dari kegiatan pengabdian ini adalah tentang pengenalan anggota tubuh dan bagian-bagian yang perlu dijaga lewat media monopoli. Pemberian pengetahuan tentang anatomi tubuh, kesehatan seksual, fungsi organ reproduksi sangat dibutuhkan anak-anak, lebih tepatnya pada masa menyongsong pubertas. Karena pubertas, bagian tubuh seksual siswa mulai tumbuh. Hal itu menyebabkan risiko kekerasan seksual meningkat. Pemberdayaan guru untuk memberi penyuluhan tentang menjaga bagian tubuh seksual pada siswa sangat diperlukan sebagai langkah antisipatif untuk meminimalisir peluang terjadinya kekerasan seksual. Pemilihanmetode tepat diperlukan agar materi yang akan disampaikan dapat terintegrasi secara optimal. Maka dari itu kreativitas dan penguasaan dalam media pembelajaran sangat dibutuhkan dimana dalam program kali ini menggunakan game monopoli. Mekanisme dari pelaksanaan kegiatan program dibagi dalam beberapa tahap, (1) tahap persiapan, pengorganisasian, (2) survey, (3) pelaksanaan, dan (4) tahap evaluasi kegiatan program. Hasil dari program kerja ini adalah meningkatnya pengetahuan baik dari para staff pengajar lewat macam media pembelajaran inovatif maupun bagi para siswa terutama terhadap materi yang disampaikan terkait knowing your body well, antusiasme dan keaktifan peserta sebagai bentuk ketertarikan terhadap program, terciptanya media pembelajaran monopoli itu sendiri, dan publikasi pada media massa.
\end{abstract}

Kata kunci-Media Belajar, Menjaga Diri, Monopoli.

\section{Abstract}

The purpose of this program aims to introduction of limbs and parts that need to be maintained through monopoly media. Giving knowledge about the anatomy of the body, sexual health, the function of the reproductive organs is needed by children, more precisely during the period of puberty. Because of puberty, parts of a student's sexual body begin to grow. That causes the risk of sexual violence to increase. Empowering teachers to provide counseling about maintaining sexual body parts for students is needed as an anticipatory step to minimize opportunities for sexual violence. The selection of the right method is needed so that the material to be delivered can be optimally integrated. Therefore creativity and mastery in learning media are needed where in this program uses monopoly games. The mechanism of implementing program activities is divided into several stages, (1) the preparation, organizing, (2) surveys, (3) implementation, and (4) evaluation of program activities. The result of this work program is an increase in knowledge both from teaching staff through a variety of innovative learning media and for students, especially to the material delivered related to knowing your body well, enthusiasm and activeness of participants as a form of interest in the program, the creation of monopolistic learning media itself, and publication in mass media.

Keywords - Learning Media, Guarding Yourself, Monopoly

\section{PENDAHULUAN}

$\mathrm{B}$ eberapa minggu terakhir Indonesia kembali dikagetkan dengan kejadian pemerkosaan dan pembunuhan terhadap seorang anak perempuan yang masih duduk di bangku SMP yang dilakukan oleh 14 orang pemuda yang juga masih berusia muda yaitu sekitar usia belasan tahun sampai dengan awal 20an. Berbagai pertanyaan dan asumsi muncul bagaimana hal seperti ini bisa terjadi. Terutama dilakukan oleh laki-laki pada usia yang dianggap masih sangat belia terhadap perempuan juga pada usia yang sangat muda.Sesungguhnya bila kita kaji kembali permasalahan kekerasan seksual yang terjadi hanyalah contoh dari sekian banyak kasus yang tidak terungkap di media. Mungkin tidak banyak yang 
menyadari atau mungkin enggan untuk tahu bahwa banyak kasus kekerasan seksual lainnya yang terjadi di sekitar kita atau pada orang-orang terdekat kita.

Persentase kekerasan yang terjadi cukup tinggi, yaitu sekitar 31\% di mana dari jumlah tersebut, jenis kekerasan yang paling banyak adalah kekerasan seksual $(61 \%)$ dan yang tertinggi adalah perkosaan (1,657 kasus), pencabulan (1,064 kasus), pelecehan seksual (268 kasus). Salah satu pendorong kekerasan seksual yaitu masih rendahnya pendidikan tentang kesehatan seksual dan reproduksi. Pendidikan ini terbatas salah satunya karena faktor budaya yang membuat masyarakat merasa tidak nyaman untuk membicarakan masalah seksual hal ini berdampak khususnya terhadap anak-anak yang lebih muda, di mana mereka tidak memperoleh informasi yang baik, bahkan lebih buruk lagi mendapatkan informasi yang salah. Padahal pengetahuan akan seksual penting sebagai langkah antisipatif terhadap hal-hal yang berhubungan dengan pelecehan seksual sebagai bentuk kekerasan seksual(https://www.liputan6.com). Untuk itu perlu adanya pendidikan seks bagi anak. Risa Fitri Ratnasari (2016). Pendidikan seks wajib diberikan orangtua pada anaknya sedini mungkin. Tepatnya dimulai saat anak usia 3-4 tahun, karena pada usia ini anak sudah bisa melakukan komunikasi dua arah dan dapat mengerti mengenai organ tubuh mereka dan dapat pula dilanjutkan pengenalan organ tubuh internal

Pemberian pengetahuan tantang anatomi tubuh, kesehatan seksual, fungsi organ reproduksi sangat dibutuhkan anak-anak, lebih tepatnya pada masa menyongsong pubertas. Karena pubertas, bagian tubuh seksual siswa mulai tumbuh. Hal itu menyebabkan risiko kekerasan seksual meningkat. Pemberdayaan guru untuk memberi penyuluhan tentang menjaga bagian tubuh seksual pada siswa sangat diperlukan sebagai langkah antisipatif untuk meminimalisir peluang terjadinya kekerasan seksual.Pemberian pengetahuan ini akan lebih baik ketika pengetahuan itu diberikan oleh guru, karena pada kenyataan siswa lebih mempercayai guru dari pada temannya. Untuk guru harus memilih metode yang tepat supaya materi yang akan disampaikan bisa terintegrasi secara optimal. Maka dari itu kreativitas dan penguasaan guru terhadap media pembelajaran sangat dibutuhkan. Media pembelajaran yang menarik diperlukan dalam kegiatan ini.

Albertus Irawan (2013) Media merupakan salah satu faktor penentu keberhasilan pembelajaran, melalui media pembelajaran ini proses pembelajaran bisa lebih menarik dan menyenangkan. Misalnya siswa sekolah dasar kelas empat yang memiliki ketertarikan terhadap warna maka dapat diberikan media dengan warna yang menarik, begitu juga halnya dengan siswa yang senang berkreasi selalu ingin menciptakan bentuk atau objek yang diinginkannya, siswa tersebut dapat diberikan media yang sesuai. Aspek penting lainnya penggunaan media adalah membantu memperjelas pesan pembelajaran, informasi yang disampaikan secara lisan terkadang tidak dipahami sepenuhnya oleh siswa. Banyak anak kesulitan belajar membaca jika menggunakan buku

Oleh karena itu, kami merasa terdorong untuk mengabdikan ilmu yang kami miliki dan membantu sebagai pengajar melalui program penyuluhan kepada siswa SD, yaitu melalui program kerja "sosialisasi 'Knowing Your Body Well' Sebagai Upaya Perlindungan Diri Menggunakan Media Monopoli Pada Siswa Kelas IV SDN Talangagung 02 Di Desa Talangagung, Kecamatan Kepanjen, Kabupaten Malang”. Pada kegiatan bidang pendidikan, kami melakukan tiga sub kegiatan, yaitu sosialisasi knowing your body well kepada kelas IV SDN 02 Talangagung; Sosialisasi mengenai beberapa macam media pembelajaran kepada semua staf/guru SDN 02 Talangagung oleh salah satu dosen Universitas Negeri Malang, dan penerapan secara langsung knowing your body well untuk perlindungan diri kepada siswa kelas IV SDN 02 Talangagung menggunakan media monopoli. Tujuannya adalah siswa dapat melakukan perlindungan diri dan melalui sosialisasi guru dapat menambah referensi mengenai macam-macam media pembelajaran dan mampu menerapkan.

\section{METODE}

Metode pelaksanaan pada kegiatan Sosialisasi "Knowing Your Body Well" Sebagai Upaya Perlindungan Diri Menggunakan Media Monopoli Pada Siswa Kelas IV SDN Talangagung 02 Di Desa Talangagung, Kecamatan Kepanjen, Kabupaten Malang adalah dengan memberikan informasi, dan penerapan. Isi kegiatan pelaksanaan terdiri dari: Sosialisasi media pembelajaran kepada guru dan staf sekolah; Sosialisasi mengenai bagian-bagian tubuh dan cara menjaganya; dan Permainan monopoli sebagai praktek langsung gabungan media inovasi pembelajaran dengan materi yang telah disampaikan. Untuk bahan dan alat yang penulis gunakan adalah kertas karton, buffalo, lem kertas, spidol, penggaris, dan gunting. Bahan dan alat tersebut yang digunakan penulis untuk membuat media monopoli. Metode pengumpulan data adalah menggunakan wawancara dan dokumentasi. Teknik analisis data menggunakan teknik analisis deskriptif yaitu dengan cara mendeskripsikan atau menggambarkan data-data yang sudah dikumpulkan lalu disajikan dalam bentuk tabel. 


\section{HASIL DAN PEMBAHASAN}

Paparan hasil pelaksanaan kegiatan program Knowing Your Body Well melalui media pembelajaran monopoli di SDN Talangagung 02Desa Talangagung, Kecamatan Kepanjen, Kabupaten Malang diuraikan dalam berikut.

Tabel 1. Paparan Hasil Pelaksanaan Kegiatan

\begin{tabular}{|c|c|c|c|}
\hline $\begin{array}{l}\text { Program } \\
\text { Kegiatan }\end{array}$ & Sasaran & $\begin{array}{c}\text { Hasil } \\
\text { Pelaksanaan }\end{array}$ & $\%$ \\
\hline $\begin{array}{l}\text { Koordinasi } \\
\text { dengan Kepala } \\
\text { Sekolah dan } \\
\text { Staff Pengajar } \\
\text { di SDN } \\
\text { Talangagung } 02\end{array}$ & $\begin{array}{l}\text { Kepala } \\
\text { Sekolah } \\
\text { dan Staff } \\
\text { SD } \\
\text { sasaran. }\end{array}$ & $\begin{array}{l}\text { Diperoleh hasil } \\
\text { yang diperlukan } \\
\text { mengenai tempat } \\
\text { dan perlengkapan } \\
\text { untuk sosialisai }\end{array}$ & $95 \%$ \\
\hline $\begin{array}{l}\text { Mempersiapkan } \\
\text { hal-hal yang } \\
\text { dibutuhkan } \\
\text { dalam Program } \\
\text { permainan } \\
\text { menggunakan } \\
\text { media } \\
\text { pembelajaran } \\
\text { monopoli }\end{array}$ & $\begin{array}{l}\text { Mahasis } \\
\text { wa KKN } \\
\text { dan } \\
\text { Perlengk } \\
\text { apan. }\end{array}$ & $\begin{array}{l}\text { Hal-hal yang } \\
\text { dibutuhkan dalam } \\
\text { Sosialisasi telah } \\
\text { disiapkan dengan } \\
\text { baik }\end{array}$ & $100 \%$ \\
\hline $\begin{array}{l}\text { Pelaksanaan } \\
\text { Program } \\
\text { permainan } \\
\text { menggunakan } \\
\text { media } \\
\text { pembelajaran } \\
\text { monopoli }\end{array}$ & $\begin{array}{l}\text { Guru SD } \\
\text { dan } \\
\text { Siswa } \\
\text { Kelas IV. }\end{array}$ & $\begin{array}{l}\text { Permainan } \\
\text { monopoli dapat } \\
\text { diterima dan } \\
\text { dipahami oleh } \\
\text { para siswa. }\end{array}$ & $95 \%$ \\
\hline $\begin{array}{l}\text { Penghargaan } \\
\text { dan Apresiasi }\end{array}$ & $\begin{array}{l}\text { Pemateri, } \\
\text { Guru, } \\
\text { dan } \\
\text { Siswa } \\
\text { Kelas IV. }\end{array}$ & $\begin{array}{l}\text { Semua berjalan } \\
\text { dengan baik } \\
\text { hanya terdapat } \\
\text { kendala sedikit } \\
\text { pada sasaran } \\
\text { siswa kelas IV. }\end{array}$ & $95 \%$ \\
\hline
\end{tabular}

Berikut adalah beberapa dokumentasi pelaksanaan sosialisasi "knowing your body well" menggunakan media monopoli sebagai upaya perlindungan diri di SDN 02 Talangagung Desa Talangagung, Kecamatan Kepanjen, Kabupaten Malang.

Perkembangan ilmu pengetahuan dan teknologi mendorong proses pembelajaran untuk lebih aplikatif dan menarik sebagai upaya untuk peningkatan kualitas pendidikan. Inovasi dan metode pengajaran yang baru dan tepat akan membantu proses pemahaman siswa sehingga siswa dapat mengaplikasikan ilmu yang diperoleh dalam kehidupan sehari-hari.
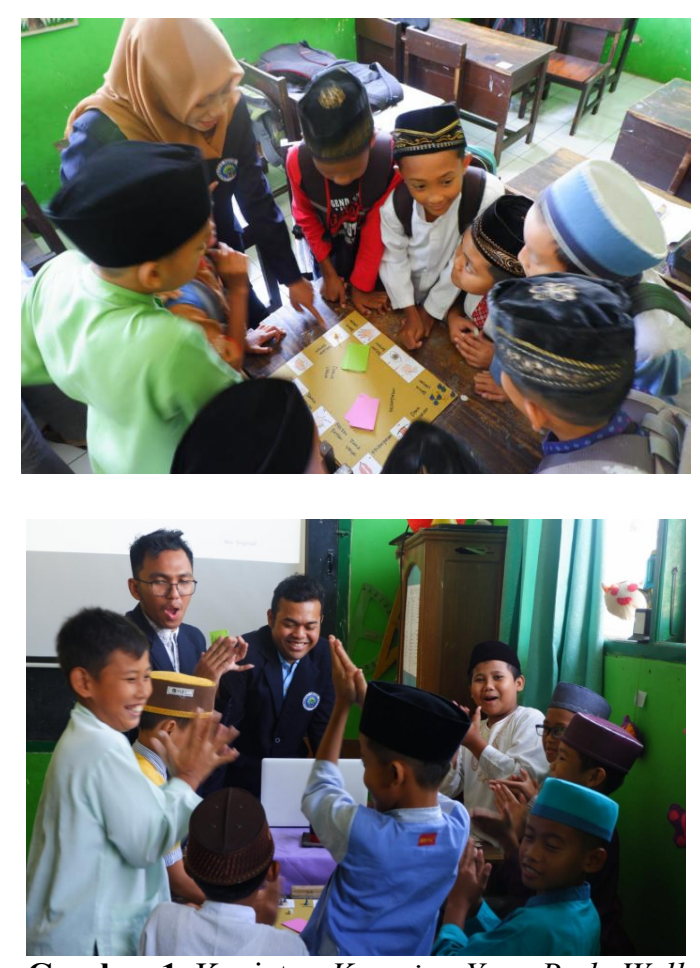

Gambar 1. Kegiatan Knowing Your Body Well

Salah satu cara untuk mendorong tercapainya pembelajaran yang efektif, digunakanlah alat bantu belajar atau yang biasa disebut media. Proses belajar mengajar atau pembelajaran merupakan suatu kegiatan melaksanakan kurikulum dalam lembaga pendidikan supaya siswa dapat mencapai tujuan yang telah ditetapkan. Tujuan pendidikan pada dasarnya mengantarkan para siswa menuju perubahan tingkah laku baik intelektual, moral, maupun sosial budaya (Aryati, 2016).

Pelaksanaan Program permainan menggunakan media pembelajaran monopoli di SDN Talangagung 02, Desa Talangagung, Kecamatan Kepanjen Kabupaten Malang terlaksana 96 persen. Kesimpulan ini didapat berdasarkan antusias dari para siswa kelas IV SDN Talangagung 02 yang aktif dalam permainan dan Tanya jawab. Tanya jawab peserta setelah permainan berisi beberapa materi didalam game monopoli dan kesan siswa terhadap game. Keberhasilan ini dianggap memenuhi harapan karena tujuan yang diinginkan tercapai. Tingkat keberhasilan dalam pelaksanaan mendekati sempurna. Terdapat faktor-faktor yang mempengaruhi keberhasilan pelaksanan program yang telah kami laksanakan. Selain karena antusias dari siswa kelas IV SDN Talangagung 02 juga karena terkonsepnya kegiatan yang akan kami lakukan dengan baik dari tahap persiapan seperti berkoordinasi dengan guru kelas IV hingga tahap pelaksanaan. Pada tahap pelaksanaan berjalan dengan sangat baik, pelaksana program dapat mengatur siswa yang cukup banyak yaitu berjumlah

Page | 51 
35. Siswa dapat menerima pesan atau materi yang disampaikan dengan baik. Hal itu dapat dilihat pada hasil post tes. Kami melaksanakan pretest, sosialisasi menngenai fungsi bagian tubuh, penerapan media monpoli untuk mengetahui seberapa besar tingkat pemahaman siswa, dan nilai itu kami jadikan sebagai postest.

Pelaksanaan program ini juga tidak lepas dari beberapa kendala. Namun kendala tersebut dapat kami selesaikan dengan alternatif pemecahan atau solusi yang. Beberapa kendala yang kami hadapi adalah Kepala sekolah tidak ada di SD saat kunjungan, Belum mempersiapkan reward untuk siswa sasaran, Keterlambatan memulai kegiatan sosialisasi dan penyuluhan, Penyampaian materi terlalu lama, penerapan media monopoli terbatas pada waktu, dan peserta kurang dapat terkkondisikan karena terlalu ramai. Namun, kami telah mempersiapkan alternatif pemecahan dari kendala-kendala yang telah kami alami pada saat sebelum dan pada pelaksanaan program dengan Mengunjungi lagi keesokan harinya sampai bertemu kepala sekolah dan meminta contact personnya, Memberi dadakan saat kegiatan program kerja berlangsung, Mempercepat kegiatan sosialisasi dan permainan monopolinya, Menjelaskan secara garis besar dan tidak memberikan refleksi dan Melakukan ice-breaking untuk mencairkan suasana.

\section{SIMPULAN}

Program kerja yang telah kami laksanakan memperoleh tingkat keberhasilaan dalam persentase yang sangat baik, yaitu 96 persen. Sosialisasi "Knowing Your Body Well" Menggunakan Media Monopoli Sebagai Upaya Perlindungan Diri berjalan sesuai harapan. Antusias siswa kelas IV SDN Talangagung 02 , terkonsepnya program dengan baik, dan kerjasama pelaksana program dengan pihak SDN Talangagung 02 menjadi faktor utama keberhasilan program. Terdapat beberapa kendala dalam pelaksanaan program seperti peserta yang sangat ramai, namun hal tersebut dapat kami selesaikan dengan mengatur siswa.

\section{DAFTAR RUJUKAN}

Aryati, netty. (2016). Media Pengena.lan Anatomi Tubuh Manusia untuk Siswa Sekolah Dasar Kelas IV Berbasis Multimedia. Skripsi. Skripi tidak diterbitkan. Yogyakarta: Fakultas Teknik Universitas PGRI Yogyakarta. (online).(http://repository.upy.ac.id/724/1/Dok
umen\%201_hlm.\%20sampul\%2C\%20Abstrak $\% 2 \mathrm{C} \% 20$ persetujuan\%Daftar\%20.pdf

Irawan, Albertus Bobby. (2013). Pembelajaran Biologi Mengenai Sistem Rangka Manusia. Seminar Riset Unggulan Nasional Informatika dan Komputer FTI UNSA 2013. (online). (http://download.portalgaruda.org/article.php?a rticle $=69469 \& \mathrm{val}=4872)$

Nunu, mahnun. (2012). Media Pembelajaran (Kajian terhadap langkah-langkah pemilihan media dan implementasinya dalam pembelajaran) : jurnal pemikiran islam, (online), vol 37, No.1 JanuariJuni 2012 .(https://www.google.com/search?source=hp\& ei=Lgs7W8a6CcXEvQSjk4-

ADg\&q $=$ jurnal + media + pembelajaran\&oq $=$ jur nal + media $+\&$ gs_l $=$ psy-

ab.3.0.0i203k1110.12357.17521.0.19504.15.14 .0.0.0.0.296.2194.0j9j3.13.0..2..0...1.1.64.psyab..2.13.2464.6..0j35i39k1j0i131k1j0i10i203k 1.275.m0_xj91s_5Q) (diakses 3 Juli 2018).

Ratnasari, Risa Fitri, dan M. Alias. (2016). Pentingnya seks untuk anak usia dini. Jurnal tarbawi katulistiwa;(online), vol 2 no. 2 .(http:openjurnal.unmuhpnk.ac.id/index.php/Ta $\mathrm{K} /$ article/download/251/197) (diakses 5 Juli 2018).

Sartikaningrum, ria. (2013). Pengembangan Media Pembelajaran Monopoli Akuntansi untuk Meningkatkan Motivasi Belajar Siswa Kelas X Program Keahlian Akuntansi SMK Negeri 1 Tempel. Yogyakarta: Universitas Negeri Yogyakarta. (online).

(http://eprints.uny.ac.id/16205/1/SKRIPSI\%20 FULL.pdf) (diakses 3 Juli 2018) 